\title{
Scribal education in Ancient Israel: The Old Hebrew epigraphic evidence
}

\author{
By Christopher A. Rollston. Bulletin of the American \\ Schools of Oriental Research 344 (2006): 47-74.
}

Reviewed By: Matt Hewitt

\begin{abstract}
There has been substantial discussion about the presence of "schools" in
Iron Age Israel (that is, Israel and Judah), with some scholars affirming that there were schools and some positing that there is no cogent evidence for them. Within this article, the Iron Age Old Hebrew epigraphic evidence is analyzed. Based on the nature of the palaeographic evidence, the orthographic evidence, and the use of hieratic numerals, it is here argued that formal, standardized scribal education was a component of ancient Israelite society during Iron II. Of course, some have posited that becoming proficient in the Old Hebrew writing system was so facile that there was no need for formal, standardized education. However, modern empirical studies of the length of time required for proficiency in a first alphabetic writing demonstrate that the field has been too sanguine about the pace of learning the Old Hebrew writing system. ${ }^{1}$
\end{abstract}

In this illustrative and thorough article, Christopher Rollston argues for the existence of "a formal, standardized scribal education" in Ancient Israel (2006, p. 47). Rollston bases his argument on a systematic analysis of the epigraphic evidence of Old Hebrew (Abbreviated $\mathrm{OH}$; otherwise referred to as Iron Age II Hebrew, ca. 1000-550 CE) and presents the following as his supporting arguments: (i) In terms of the ductus, the stance, and the relative spatial relationship of graphs, the Old Hebrew $(\mathrm{OH})$ script: (a) displays synchronic consistency, (b) demonstrates discernable, diachronic development, and (c) differs markedly from those of nearby polities (Phoenicia, Arameans); (ii) In terms of orthography, the $\mathrm{OH}$ script exhibits synchronic (and arguably regional) consistency with distinctive features that were in opposition with the features of the Phoenician and Aramaic national scripts; and (iii) In terms of content, hieratic numerals (which derive from a complex number system originally borrowed from Egypt) were inscribed on many $\mathrm{OH}$ documents, suggesting that an administrative or governing body

\footnotetext{
${ }^{1}$ Rollston (2006, p. 1).
} 
routinized their usage (and practical dissemination) throughout Iron Age Israel.

Rollston supplements his argument for a formal, standardized scribal education in Iron Age Israel by demonstrating the systematic qualities of abecedaries and predictable epistolary greetings, particularly as they implicate standardized oversight in scribal practices. This article is an extension of his 1999 doctoral dissertation at Johns Hopkins University ${ }^{2}$, in which he provides a complete synopsis of the typological development of the $\mathrm{OH}$ script(s). It should be noted that the present article provided the basis for Chapter 5 of his "Writing and Literacy in the World of Ancient Israel: Epigraphic Evidence from the Iron Age," which slightly revises this material.

Rollston begins by presenting an "[i]ntroduction to the problem" of 'schools' within Iron Age Israel (comprising both Israel and Judah) (p. 47). He surveys the pre-existing literature and outlines two contested approaches - one for and one against the existence of 'schools'. This survey includes the works of many Semitists, epigraphers, and Old Testament scholars, such as André Lemaire (1981), James L. Crenshaw (1985), and G. I. Davies (1995). The scholars who belong to the first persuasion largely insist that there is insufficient evidence in the archaeological and paleographic record to suggest the presence of schools in Iron Age Israel. Early on, Rollston challenges these scholars' tenuous proposal that the $\mathrm{OH}$ writing system - an abjad/abecedary consisting of 22 distinct graphs - would have been decidedly easy and quick to learn in the Iron Age. W. F. Albright ${ }^{3}$ (1960) asserts that "the 22-letter alphabet could be learned in a day or two by a bright student and in a week or two by the dullest" (p. 123). Rollston retorts, however, that this claim presupposes the relative ease with which only a literate learner with previous orthographic exposure might learn the script (p. 49). In actuality, although the Iron Age scribes (probably adults) would have been fully competent speakers of $\mathrm{OH}$, they would have required substantial time and effort to acquire a first writing system.

In support, Rollston alludes to three modern, empirical studies on the developmental phases associated with the primary acquisition of wordreading and word-spelling (p. 48). A study conducted by Iris Levin et al. (1996) reveals that modern Israeli children take roughly five years to learn the core mechanics of the modern Hebrew orthography (which does not differ significantly from $\mathrm{OH}$ orthography). Furthermore, ancient scribes were not only expected to learn basic $\mathrm{OH}$ orthography to be proficient in the writing system, but also to be able to produce consistent and inerrant (or at least minimally imprecise) documents, with standard graph spacing and sizes, all the while adhering to relatively rigid 'ceiling' and 'floor' lines that enclose every line of text (p. 48). These scribal guidelines (corroborated through

\footnotetext{
2 "The Script of Hebrew Ostraca of the Iron Age: $8^{\text {th }}-6^{\text {th }}$ Centuries BCE"

${ }^{3}$ A seminal archaeologist and Semitic philologist.
} 
paleographic analysis) are not trivial, and Rollston argues that they necessitate a reassessment of the argument and of the definition of 'schools'.

The term 'school' is semantically rich in English due to its conceptual heritage in the Western academic tradition. Some scholars have argued that there is no justification for the argument for 'schools' in Iron Age Israel, defined by Crenshaw as "[a] professional education, which involved both reading and writing, at a specific location to which young people came and for which fees were paid to a teacher," and by R. N. Whybray as an established institution that included "organized classes comprising a number of pupils, whose teachers were 'professional' in the sense that they were not the parents, or relations, or even tribal heads, of the pupils" $(1985$, p. 602; 1974, p. 35). These definitions obscure the intended question by imposing certain restraints on what must count as a 'school'. Rollston responds by suggesting that even many modern classrooms would not fulfill the criteria imposed by these definitions (e.g., part-time or volunteer teachers, teacher-student familial relations, etc.). Rather, he resolves the problem by defining it as follows: "[T]here was a mechanism in ancient Israel (defined broadly) that facilitated and orchestrated formal, standardized scribal education" (p. 50; emphasis original). By refuting earlier contentions and formulating a precise definition of the term 'school' without superfluous constraints, he is refining the question in pursuit of a more satisfactory answer.

The rest of the paper is mostly comprised of a step-by-step analysis of diagnostic, cursive graphs in $\mathrm{OH}$, preceded by a general defense of the efficacy and legitimacy of invoking paleography as evidence in favor of scribal education. Rollston highlights prior, pivotal studies that have become the cornerstones of Semitic paleography (including Cross, 1961, 1982, 2003; Cross \& Freedman, 1952; and Bordreuil, Israel, \& Pardee, 1996), and which have established the disciplinary parameters of modern scientific paleography (especially as it concerns cursive scripts). He concludes that "statements made on the basis of a large(r) amount of paleographic data for a script series are more definitive than statements made on the basis of modest amounts of data... [and] inscriptions... that are clear... are the most valuable" (p. 51). He exclusively focuses on cursive scripts and thereby restrains his corpus to that of extant cursive inscriptions from Iron II Israel (as opposed to monumental inscriptions).

Rollston establishes his epigraphic corpus by summarizing the major, relevant archaeological discoveries and how they have traditionally factored into the quintessential (i.e., Cross' and Naveh's) script charts and typologies. Script charts provide relative, chronological lists of graphs that (ideally) derive from disparate sites and that track the (approximate) diachronic development of a script. These remains ${ }^{4}$ exhibit variants of $\mathrm{OH}$ and derive from the eighth through sixth centuries BCE. The notable corpora include the Kuntillet Ajrud inscriptions, Samaria Ostraca, Samaria Joint Expedition inscriptions, Lachish

${ }^{4}$ i.e., inscriptions or 'ostraca' - "ink inscriptions written on potsherds" (Rollston, 2010, p. 147). 
Ostraca, Arad Ostraca, and Meșad Ḥashavyahu inscriptions. For each corpus, Rollston cites its editio princeps ${ }^{5}$ and any important, subsequent treatments, directing readers toward seminal analyses. By extracting diagnostic features from these ostraca, he aims to identify synchronic consistency and traceable, diachronic development within the $\mathrm{OH}$ cursive, epigraphic record. Moreover, he stresses the importance of provenance for anchoring script typologies according to stratigraphic layers and other external checks. Invoking the paleographic approach yields relative, typological developments which integrate with and augment stratigraphic and pottery chronologies (p. 51).

Rollston goes on to identify key features of the cursive via diagnostic graphs ${ }^{6}$. He notes that it is crucial that graphic features should be legible, derive from secure primary contexts, and have parallels in multiple sites to qualify as diagnostic (p. 51). Otherwise, they might represent scholarly misreadings, scribal errors, or geographic idiosyncrasies. While this work is commendable in its own right, Rollston reminds the reader that a comprehensive survey of script charts and their diachronic developments is not his focus. Rather, he simply sketches their most important features and directs interested readers to his 1999 dissertation. In effect, he provides a useful summary of paleographic analysis for readers who are unfamiliar with the process, and includes short script charts with his personal drawings throughout (see an example in the ensuing discussion of 'national' script features).

Of the many diagnostic graphs that he treats, 'aleph may function as an exemplar of his analytic method. Rollston traces the development of 'aleph from among its earliest cursive attestations at Kuntillet 'Ajrud (ca. $800 \mathrm{BCE}$ ) through its form in the early sixth century at Lachish. Included in his summary are descriptions of the stance and ductus of the graphs (coincident with objective (i) in the introductory paragraph). In the early eighth century, 'aleph had a long vertical shaft (substantially longer than either horizontal stroke), typified in the Kuntillet 'Ajrud inscriptions (p. 54). Over time, the cursive displayed innovating features as a result of its frequent and quickened production. In particular, a 'tick' or flourish was added to the bottom horizontal stroke of 'aleph, a feature manifested in the Samaria ostraca (ca. early-mid $8^{\text {th }}$ century) but is unattested later in the Arad and Mesad Hashavyahu inscriptions (ca. $7^{\text {th }}$ century) (p. 54). The latter two sites instead demonstrate two other innovating, scribal features - namely, a shortened downstroke and a leftward slant of the entire graph. Rollston's script chart offers the reader a quick summary (in hand-copied graphs) of the diachronic development with 'aleph (p. 54). He maintains this convention for each diagnostic graph in the paper. While the chart lacks a demonstration of the synchronic consistency (or differentiation) of 'aleph at any given typological stage, his explanations cite analogous examples at length. Again, his aim is not to provide a comprehensive summary of the history of $\mathrm{OH}$ cursive, but to

\footnotetext{
${ }^{5}$ First edition.

${ }^{6}$ Graphs with geographically and synchronically generalizable distinctive features.
} 
use these summaries as evidence in favor of his argument for formal, scribal education in Iron II Israel.

In similar fashion, Rollston chronicles the progression of innovation in the ductus and stance of the $\mathrm{OH}$ cursive graphs he, kaph, mem, qoph, and sin. $\mathrm{He}$ occasionally supplements his analysis by introducing alternative sources of evidence for paleographic analysis - for example, ink blotting with he: "[r]egarding ductus, the evidence suggests that the top horizontal was normally made from right to left, and that the vertical stroke was a downstroke (note ink blotting)" (p. 55). The sum of his analyses of ductus, stance, and ancillary features (such as ink blotting) succinctly illustrates both the synchronic consistency and diachronic development of $\mathrm{OH}$ from the eighth to sixth centuries and, in his own words, "necessitates a mechanism: formal, standardized education" (p. 58). Furthermore, having demonstrated the diagnostic efficacy of investigating individual graphs, he proceeds with a brief case study of a two-graph sequence: samek-pe. In cursive $\mathrm{OH}$, the head of samek consistently breaks through the conventionalized, but generally unwritten, 'ceiling line' (which bounds all but a few graphs), while pe sits well within the 'ceiling' and 'floor' lines. Therefore, in all extant examples of their immediate sequence, the head of samek stretches high above pe and illustrates a conscious effort by scribes to maintain relative height relationships. Rollston comments, "[c]oincidence surely cannot account for [this feature], but curriculum can readily do so" (p. 59). He is thus claiming that both the shapes of graphs and the relationships between them demonstrate consistent, traceable developments in support of his hypothesis.

Rollston subsequently ventures beyond the analysis of $\mathrm{OH}$ scripts to those of the Ancient Near East (ANE) in general to justify his claim that there was indeed a dedicated, formal, scribal education which belonged to Iron Age Israel and was not an extension of a nearby polity's governance or administration (coincident with objectives (i.c) and (ii) in the introductory paragraph). His first source of evidence comprises isographs in the scripts of regional polities - idiosyncratic features associated with particular regions, languages, and cultures. The three scripts which are pertinent to his discussion are $\mathrm{OH}$, Phoenician, and Aramaic from the ninth century BCE onwards. He inspects the two graphs bet and dalet and demonstrates that there are innovating trends which differentiate certain regional polities' scripts. For example, the $\mathrm{OH}$ dalet preserves a closed headstroke from the eighth through the sixth centuries (e.g., from Kuntillet 'Ajrud/Reisner Samaria through Lachish II) while the Aramaic dalet tends to open its head over time (e.g., from the Nimrud Ostracon to the Saqqarah Papyrus) (p. 60). This is typical of a demonstrable pattern in Aramaic cursive, whereby scribes open many graphic heads that $\mathrm{OH}$ scribes keep closed, e.g., those of dalet, bet, 'ayin, and

TABLE 7 : Bet

\begin{tabular}{|c|c|c|c|c|}
\hline Lachish 2 & $\begin{array}{l}\text { Hebrew } \\
\text { Samaxia } 18\end{array}$ & $\begin{array}{l}\text { Aramaic } \\
\text { Saqqarah Papyrus }\end{array}$ & $\begin{array}{l}\text { Aramaic } \\
\text { Amsan citadel }\end{array}$ & $\begin{array}{l}\text { Phoenician } \\
\text { Kition Bowl }\end{array}$ \\
\hline
\end{tabular}


reš (ibid.). The Phoenician script, all the while, preserves a closed head, but lacks other innovating features of the $\mathrm{OH}$ cursive script such as the lengthened top, horizontal stroke which breaks through the vertical downstroke evident in the Lachish Ostraca (ibid.). The following table exhibits the variation in open-headedness among 'national' scripts: ${ }^{7}$

The second crucial source of evidence for differentiating regional scripts was orthography. The orthographic feature which has enjoyed the most rigorous and thorough analysis in paleography since the 1950 s has been $\mathrm{OH}$ matres lectionis (p. 61). Matres lectionis are consonantal representations of homorganic non-obstruents. Rollston sketches the variations between the three, aforementioned Northwest Semitic scripts in the Iron Age II period. While, in all likelihood, matres lectionis ultimately derived from Aramaic writing, each regional script subsequently developed its own unique regularities for employing them. ${ }^{8}$ For example, $\mathrm{OH}$ regularly marked final $/ i /$ with yod (e.g. $\mid k i /$ and $<k y>$ 'for; since') from the eighth through sixth centuries, while Phoenician lacked final matres lectionis during the same period and wrote the word from the previous example as $<k>$ (p. 61). Iron Age Aramaic continued to utilize final matres lectionis during this period. These findings respond to challenges posed by scholars like Weeks, who states that "it is really quite hard to come up with alternative spellings of a word when the alphabet offers little or no choice of characters to represent a given sound" (p. 61). Rollston's summary demonstrates that the exact opposite is true. These three polities, in close proximity, developed their own idiosyncratic, orthographic conventions, each with "alternative spellings" of the same words (p. 61).

The information delineated above contributes to and culminates in one of the most convincing sections of the paper: Rollston's contention that the $\mathrm{OH}$ system of matres lectionis reveals diachronic development and synchronic consistency in the epigraphic, $\mathrm{OH}$ cursive record, and not only a regional or dialectal contrast. He offers the following orthographic chronology: $9^{\text {th }}-8^{\text {th }}$ century, cursive $\mathrm{OH}$ attests the usage of final matres lectionis (yod for $/ i /$; waw for $\mid u^{-} /$; he for $\left|e^{-}\right|,\left|a^{-}\right|$, and $/ o^{-} /$) and an arguably complete lack of internal matres lectionis; $8^{\text {th }}-7^{\text {th }}$ century, cursive $\mathrm{OH}$ attests the usage of the same final matres lectionis, as well as examples of what may be the incipient use of internal matres lectionis ( waw for $/ \bar{u} /$; yod for $/ \bar{i} /$ ); $7^{\text {th }}-6^{\text {th }}$ century, cursive $\mathrm{OH}$ attests more frequent usage of the aforementioned final and internal matres lectionis (p. 65). ${ }^{9}$ Even dialectal differences, notably with matres lectionis between Northern/Israelite and Southern/Judaean dialects, maintain regularized conventions and develop distinctly and faithfully over time. As Rollston states, "[r]andom dialect variation does not occur. Rather, consistency is the norm" (p. 65). All of these observations are harmonious with the implementation of a formal, standardized education in Ancient Israel.

\footnotetext{
${ }^{7}$ This table was excerpted from Rollston (2006, p. 60).

${ }^{8}$ See Cross and Freedman (1952, p. 31-34; 58-59) for Aram as the source of matres lectionis during the early Iron Age prior to the eighth century.

${ }^{9}$ In accordance with Cross and Freedman EHO (1952, p. 59).
} 
Finally, Rollston supplements his primary sources of evidence (comparative paleography and orthography) with short case studies of hieratic numerals, abecedaries, and epistolary documents (coincident with objective (iii) in the introductory paragraph). First, the consistent use of hieratic numerals at disparate sites throughout Iron Age II Israel suggests that a formalized, administrative body managed their diffusion throughout scribal educational practices, probably for their efficiency and systematicity (although they were notoriously complicated, and completely foreign to the contemporary linguistic situation) (p. 66). Second, abecedaries suggest minimally that an educational system disseminated a normalized alphabet order, and they suggest maximally that students were required to conduct writing exercises (p. 67). Third, predictable epistolary greetings in $\mathrm{OH}$ letters (normally a blessing by the sender and invocation of the deity, followed by a transitional function word or constituent) betray common structures throughout the world of Iron Age II Israel and complement the running accumulation of data in favor of a formal, standardized scribal education (p. 67).

In his conclusion, Rollston summarizes his empirical analyses and asserts that "[i]t is simply not feasible to attempt to account for the Old Hebrew epigraphic data without positing some sort of formal, standardized education" (p. 67). To justify his assertion, R[ollston?] proposes that the only organization with such extensive influence in Ancient Israel would have been a centralized political administration, whose administration frequently required scribes to document royal affairs, decisions, and economic activities. A survey of the corpus of $\mathrm{OH}$ epigraphs even demonstrates that "the majority... are administrative (and military) in nature" (ibid.). However, even if the state administrated this education, it need not have been located in a state-run or state-funded building; rather, schooling could have occurred in domestic contexts under executive oversight. While these last intimations remain speculative for lack of archaeological evidence, he maintains that the core of his argument is true: "[a]d hoc, nonstandardized education would perforce have yielded substantial variations in the Old Hebrew epigraphic evidence, and that is simply not the way that the Old Hebrew evidence patterns" (ibid.).

In this succinct survey of the relevant Iron Age II inscriptions, Rollston successfully demonstrates the formal nature of $\mathrm{OH}$ cursive at a number of levels - paleographic, orthographic, conventional, and sociolinguistic. He offers the reader a concise summary of the necessary background information on Hebrew paleography, distinguishing this work from the preponderance of ANE, paleographic literature whose rigorous jargon can be cumbersome for novices. Furthermore, when he does omit relevant details or specifications, he is sure to direct the reader to the appropriate, classic treatment. Thus, he does not reach beyond his limited scope in this paper and meaningfully adds to the preexisting literature (e.g., Cross; Naveh; Lemaire; Pardee; and many others).

To fully understand the significance of Rollston's hypothesis, one must first understand the state of standardized scribal education in the Ancient Near and Middle East. First, this phenomenon is well known in Mesopotamia in 
both the archaeological and paleographic record (cf. Oppenheim, 1977; Veldhuis, 1996, 1997; Tinney, 1999; Robson, 2001; Delnero, 2010; and others). Numerous tablets have been discovered containing practice texts in Babylonian schools, where students were tasked with the comparatively more impressive task of learning cuneiform. These might sound familiar to one of Rollston's readers, as they sound alluringly similar to his depiction of alphabetic and exercise tablets (p. 67). However, it has not been generally agreed that there was an analogous structure in Ancient Israel. ${ }^{10}$ Much of this argument extends from the total absence of its mention in the Hebrew Bible, and the lower economic status of such polities as Judah, which lacked the extensive resources of a sprawling, militaristic empire like Babylon or Assyria (p. 47). With this background in mind, Rollston's claim is rendered all the more impressive, as its conclusions seriously implicate the governing power and administration of the state in Ancient Israel. ${ }^{11}$

Regardless of its influential or successful status, Rollston's article has its flaws. The two notable misspellings in need of correction are as follows: (i) the heading of the section on page 64 reads "Diachonic [sic] Development and Synchronic Consistency", where the first word should clearly be corrected to "Diachronic"; (ii) He mistakenly recalls his example of the diagnostic value of relative spatial relationships between immediate graphs as a comparison of " 'ayin and pe", and should rather have written "samek and pe" (p. 67). For the naïve reader, this second mistake could prove detrimental to her comprehension, as the shape of samek differs markedly from 'ayin. This leaves him at the danger of being misunderstood, as he never provides a clear handwritten example of 'ayin by which a reader could distinguish the two graphs.

Furthermore, although he does not purport to furnish the reader with a comprehensive defense of script charts in general, Rollston deprives the reader of any easily accessible, graphic representation of synchronic consistency (or marginal deviation from a prototypical form) in his paleographic analyses. His drawings are good ones, but they lack synchronic explanatory and descriptive power. Had he included just a few more graphs at each typological stage, he would have significantly increased this article's accessibility (one must keep in mind that this article eventually featured - in a slightly edited

${ }^{10}$ Since Rollston's publication of this article, he has hypothesized that the City of David Inscribed Stone (IAA 1986-394) may have functioned as "part of some curricular activities" given that it includes both "a trained hand and a remedial hand" on the same inscription (2012, p. 195; 190). If he is correct, this lends significant credibility to the present hypothesis.

${ }^{11}$ Though, it should be noted, the government need not have devoted overwhelming resources to this endeavor. As N. Veldhuis remarks, Old Babylonian schools were not located in expansive administrative complexes; rather, they were small and located in domestic areas and probably comprised no more than 10 students, with likely 4 or less in each class (1996, p. 13). It seems that similar systems could not have posed a significant economic drain, even on the smallest administrations. 
form - in his textbook "Writing and Literacy in the World of Ancient Israel: Epigraphic Evidence from the Iron Age"). This is a shame, since the article is a benchmark in understanding the relationship between the $\mathrm{OH}$ cursive script and scribal society. Even for readers solely interested in the study as it pertains to Biblical scholarship, it is pertinent to understand the significance of synchronically consistent scribal practices with regards to socio-political identity in the ANE.

The implications of this section even evade Rollston himself at times. He reiterates throughout his comparative orthographic analysis that "there were orthographic "alternatives'" available to Iron Age II scribes (p. 63). Consequently, he could have improved his critique of the presuppositions concerning the acquisition of $\mathrm{OH}$ orthography with these data. While he does demonstrate that the primary acquisition of one's first writing system takes significant time, he misses an alternative angle of this critique. Since scribes were not privileged with straightforward sound-symbol correspondences for their script, ${ }^{12}$ and since they standardized altogether different sound-symbol correspondences within each 'national' script, the process of acquiring a particular script would not have been remarkably simple - in fact, just the opposite. It is reasonable to assume that scribes would have had relatively frequent contact with the script conventions of their neighbors. However, the synchronic consistency within each regional script in the epigraphic record demonstrates that scribes were acutely equipped to regularize their practices - a feat which "reflects the sophisticated knowledge of trained professionals" (p. 61). It seems impossible to account for these data without "positing some kind of formal, standardized education for scribal elites, regardless of the precise locus and aegis" (p. 68).

Rollston's comparative analysis of 'national' scripts bears heavily upon the field's prior conception of the relationship between a region and its script. In Cross and Freedman's seminal epigraphic study, "Early Hebrew Orthography: A Study of the Epigraphic Evidence" (1952), they conclude that the system of matres lectionis used in $\mathrm{OH}$ from the $9^{\text {th }}$ century onwards derived from Aramaic scribal practices, and were subsequently borrowed into Moabite in the mid-9 $9^{\text {th }}$ century (EHO, 57). Rollston draws a similar conclusion in his comparative orthographic analysis, but ventures that paleographic analysis demonstrates a (plausibly conscious) differentiation of scripts by these same polities (p. 59-60). Thus, from the $8^{\text {th }}$ to $6^{\text {th }}$ centuries, the scripts of these proximal nations continuously diverged, suggesting a burgeoning self-identification by their peoples. His thorough and insightful comparison of 'national' scripts benefits any scholar of the ANE.

In summary, Rollston outlines a vast body of paleographic work that spans a half century, delivers a concise investigation of orthographic conventions throughout the ANE, demonstrates a flexible orientation towards the 'problem of schools' with his studies of hieratic numerals and

${ }^{12}$ See especially the diachronically varied representation of non-obstruents by matres lectionis. 
abecedaries/exercise tablets, and commendably correlates these data to illustrate the necessity of positing a formalized, scribal education for $\mathrm{OH}$ cursive in Iron Age II Israel. The article owes its potency to Rollston, who organized the relevant data for both the naïve and professional reader. Accordingly, this article deserves a seat among many other critical epigraphic and paleographic works of the last few decades. Rollston delineates the intricacies involved in the $\mathrm{OH}$ writing system which could not have been informally passed down from scribe to scribe, but must have been accomplished by a formalized education at the behest of the state (or some such administration). The synchronic consistency and diachronic development evident in these scripts, which had alternatives for representation, attest to the systematic and regularized knowledge of ancient scribes. This formalized educational system informs our knowledge especially of Ancient Israelite and Judahite scribal practices and also amplifies our awareness of the role of writing in the larger purview of ancient Palestine and the Transjordan. Scribes under the patronage of the state received a formal education which standardized the synchronic status of a given script, and which, over time, systemically determined the chronological path that the scripts followed. Rollston familiarizes us with what remains of this system the traces of their fascinating society and academic practices. 
Albright, W. F. (1960). Discussion in City invincible: A symposium on urbanization and cultural development in the Ancient Near East, eds. C. H. Kraeling and R. M. Adams, 94-123. Chicago: University of Chicago.

Bordreuil, P., Israel, F. \& Pardee, D. (1996). Deux ostraca paléo-hébreux de la collection Sh. Moussaieff. Semitica, 46, 49-76.

Crenshaw, J. L. (1985). Education in Ancient Israel. Journal of Biblical Literature 104, 601-15.

Cross, F. M. (1961). The development of the Jewish scripts. The Bible and the Ancient Near East: Essays in Honor of William Foxwel Albright, ed. G. E. Wright, 133-202. Garden City, NY: Doubleday [Republished in Cross (2003), 3-43].

Cross, F. M. (1982). Alphabets and pots: Reflections on typological method in the dating of human artifacts. Maarav 3, 121-136 [Republished in Cross (2003), 344-350].

Cross, F. M. (2003). Leaves from an epigrapher's notebook: Collected papers in Hebrew and West Semitic paleography and epigraphy. Harvard Semitic Studies 51. Winona Lake, IN: Eisenbrauns.

Cross, F. M. \& Freedman, D. N. (1952). Early Hebrew orthography: A study of the epigraphic evidence. American Oriental Series 36. New Haven: American Oriental Society.

Davies, G. I. (1995). Were there schools in Ancient Israel? Wisdom in Ancient Israel: Essays in honour of J. A. Emerton, eds. J. Day, R. P. Gordon, and H. G. M. Williamson, 199-211. Cambridge: Cambridge University.

Delnero, P. (2010). Sumerian extract tablets and scribal education. Journal of Cuneiform Studies, 62, 53-69.

Lemaire, A. (1981). Les écoles et la formation de la Bible dans l'ancien Israël. Orbis Biblicus et Orientalis 39. Göttingen: Vandenhoeck \& Ruprecht.

Levin, I., Share, D. L., \& Shatil, E. (1996). A qualitative-quantitative study of preschool writing: Its development and contribution to school literacy. The science of writing: Theories, methods, individual differences and applications, eds. M. Levy and S. E. Ransdell, 271-93. Mahwah, NJ: Erlbaum. 
Oppenheim, A. L. (1977). Ancient Mesopotamia: Portrait of a dead civilization, ed. Erica Reiner, 2nd edition. Chicago: University of Chicago Press.

Robson, E. (2001). The tablet house: a scribal school in Old Babylonian Nippur. Revue d'assyriologie et d'archéologie orientale, 93(1), 39-66.

Rollston, C. A. (1999). The script of Hebrew ostraca of the Iron Age: $8^{\text {th }}-6^{\text {th }}$ centuries BCE. Ph.D. dissertation, Johns Hopkins University.

Rollston, C. A. (2006). Scribal education in Ancient Israel: The Old Hebrew epigraphic evidence. Bulletin of the American Schools of Oriental Research 344, 47-74.

Rollston, C. A. (2010). Writing and literacy in the world of Ancient Israel: Epigraphic evidence from the Iron Age. SBL Archaeology and Biblical Studies, vol. 11. Atlanta: SOCIETY OF BIBLICAL LITERATURE.

Rollston, C. A. (2012). An Old Hebrew stone inscription from the City of David: A trained hand and a remedial hand on the same inscription. Puzzling out the past: Studies in Northwest Semitic languages and literatures in honor of Bruce Zuckerman, eds. M. J. Lundberg, S. Fine, and W. T. Pitard, 189-196. Culture and History of the Ancient Near East, vol. 5. Leiden: Brill.

Tinney, S. (1999). On the curricular setting of Sumerian literature, Iraq, 61,159-172.

Veldhuis, N. (1996). The cuneiform tablet as an educational tool. Dutch Studies on Near Eastern Languages and Literature 2, 11-26. Retrieved from nes.berkeley.edu/Web_Veldhuis/articles/veldhuis_ds-nell_21.pdf

Veldhuis, N. (1997). Elementary education at Nippur: The lists of trees and wooden objects. Ph.D. dissertation, Groningen University. Retrieved from http://www.rug.nl/research/portal/publications/pub(d7539f729851-4b83-841f-886ef19cb1be).html

Weeks, S. (1994). Early Israelite wisdom. Oxford: Clarendon.

Whybray, R. N. (1974). The intellectual tradition in the Old Testament. Beiheft zur Zeitschrift für die alttestamentliche Wissenschaft. 135. Berlin: de Gruyter. 